DOI: https://doi.org/10.24297/jssr.v15i.8745

\title{
Determinants of Bank Profitability Empirical Evidence from Vietnamese Commercial Banks in The Periods Of 2013 To 2018
}

\author{
Nguyen Ngoc Minh Dan ${ }^{1}$, Vu Tuan Anh² \\ ${ }^{1,2}$ International University, HCM \\ anh.tuan.vu.ueh@gmail.com
}

\begin{abstract}
This research concentrates on the determinants of the profitability of the Vietnamese Commercial Banks. Both internal and external variables regarding the profitability of commercial bank sector will be focused in the analysis. Data over the period of 2013 to 2018 for 29 Vietnamese Commercial Banks i is obtained from via Stock Exchange or media. Fixed effect panel model are used to analyze the determinants of the profitability. By using this, we ensure for the effectiveness of the test result in terms of hypothesis along with size in order to get consistent results.

The research is based on the scientific approach of quantitative methods to solve the problems posed, practical and effective service for the completion of the research purpose. The secondary data collected from the worldbank.org, vietdata.vn and annual reports (financial statement, balance sheet, etc.) of Vietnamese commercial banks in the 2013-2018 period to create asymmetric data tables will be processed on STATA software.
\end{abstract}

Keywords: Vietnamese Commercial Banks, Profitability, Panel Data Analysis

\section{Introduction}

After more than 34 years renovating the economy, many fields and many economic sectors has been giving and providing the environment as well as favorable conditions for development expansion. Operating in an era of open economy, many economic relationships between businesses as well as countries are formed and developed, these are really favorable opportunities for banks to gain much profit and high effectiveness in business operations. Banks are always volatile with many opportunities and potential risks with the most intense level of competition. Therefore, it is very difficult to maintain and enhance their position in the market, requiring banks to always take an active, appropriate and ready approach to the market risks, threats as well as competitive pressure in the market.

In the current economic conditions, efficient business is the top concern of economic organizations and banks. To determine the bank's business performance, profit is an important factor in be considered. Profit not only determines the survival of the banks but also affirms the competitiveness and bravery of the bank in the market. The stability and development of the bank is something to be concerned about and ensured, as well as the lives of employees and encourages them to devote themselves to their work in particular and to economic development in general.

In the world, there have been many studies on the factors affecting the profitability of commercial banks, most studies focused on analyzing the factors affecting the profitability of commercial banks. This paper seeks to identify the determinants of Vietnamese Commercial Banks from 2013 to 2018. For these reasons, the authors choose the topic: "Determinants of Bank Profitability: Empirical Evidence from 
Vietnamese Commercial Banks in the periods of 2013 to 2018" to find directions and solutions to help banks improve profits in the current period.

Therefore, this paper well clarify some questions below:

Question 1: What factors affected the profitability of Vietnamese commercial banks in the period 20132018 ?

Question 2: How compelling is the impact of these factors on the profitability of Vietnamese commercial banks in the period 2013-2018?

Question 3: From a practical point of view, what are the good practices for Vietnamese Commercial Banks to enhance the performance?

\section{Materials and Methods}

There is a huge amount of literature coping with factors that affect the profitability of the bank. Some empirical studies on the bank profitability are country specific, while others have focused on the others. Examples of single country research are those for Nigeria (Adeusi 2014, Aluko 2014), Colombia (Barajas et al.,1999), Brazil (Afanasieff et al., 2002), Croatia (Kundid et al., 2011), Greece (Mamatzakis, 2003; Kosmidou, 2008; Alexiou and Sofoklis, 2009), Tunisia (Naceur, 2003; Naceur and Goaied, 2001), India (Badola and Verma, 2006), China (Heffernan and Fu, 2008), Taiwan (Ramlall,2009; Chen and Yeh, 1998), Philippines (Sufian and Chong, 2008), Malaysia (Guru et al., 1999), Pakistan (Javaid, 2011; Burki, 2006), Japan (Lui and Wilson, 2010), Korea (Sufian, 2011)

In Vietnam, there are also papers that investigated bank profitability. Tam and Trang (2017) examine the profitability of banks in 9 commercial banks during the period from the $2017-2013$, finding that the profitability of these banks are determined by several internal and external factors. Jonathan and Vinh (2017) also assess the banks' profitability, finding that there is a positive impact on profitability by capital adequacy, the level of riskiness, productivity and bank operation costs. Duong, Huyen, and Huong, analyzing the profitability of Vietnamese commercial banks, found that foreign ownership, cost to income and the level of credit risk, negatively influenced on profitability of Vietnamese banks, while state ownership, size of assets, and macroeconomic factors (GDP and inflation) are not statistically significant to the profitability and the relationships among capital structure, liquidity risk and the profitability were combined.

Below table Summarizes the variables used in this paper and their expected effect on bank returns

Table: Variables description

\begin{tabular}{llll}
\hline Symbol & Variables & Proxy & Expected sign (+/-) \\
\hline Dependent Variables & & \\
\hline ROA & Return on Assets & Net profit/ Asset & \\
ROE & Return in Equity & Net profit/ Equity & + \\
\hline Independent Variables & & & + \\
\hline Size & Size & Size & + \\
NPL & Non-performance Loan & NPL ratio & \\
INF & Inflation & Inflation ratio & \\
GDP & Gross DomesticProduct & GDP ratio & \\
Capital & Capital to asset & Capital/Asset & + \\
LTD & Loan to Deposit & Loan/Deposit & - \\
DTA & Deposit to Asset & Deposit/Asset & + \\
CTD & Cash to Deposit & Cash/Deposit & - \\
DEPOSIT & Depositto Asset & Deposit/Asset & + \\
\hline
\end{tabular}


From the above literature, the research model is built as follows:

Model 1: Model for ROA based on the previous evidences of Anna P. I. Vong \& Hoi Si Chan (2016), Sehrish GuL, Faiza Irshad \& Khalid Zaman (2011):

$R O A=\beta O+\beta 1 S I Z E+\beta 2 N P L+\beta 3 I N F+\beta 4 G D P+\beta 5 C A P I T A L+\beta 5 L O A N+\beta 5 L T D+\beta 5 D T A+\beta 6 C T D+$ $\beta 7 D E P O S I T+\varepsilon$

\section{Where:}

$\beta 0$ : Free coefficient.

$\beta 1, \beta 2, \beta 3, \beta 4, \beta 5, \beta 6, \beta 7$ : unknown parameters.

ع: Error.

Dependent variable: ROA: Return on asset.

Independent variable: SIZE: Firm size.

NPL: Non-performance loan.

INF: Inflation rate.

GDP: Gross domestic product.

CAPITAL: Capital to asset.

LOAN: Total loan to total asset.

LTD: Loan deposit ratio.

DTA: Deposit asset ratio.

CTD: Cash deposit ratio.

DEPOSIT: Deposit to asset

Model 2: Model for ROE conducted by the studies of Md. Asadul Islam, Md. Nazirul Islam Sarker, Mahabub Rahman, Arifin Sultana, AZM Shafiullah Prodhan (2017), Anna P. I. Vong \& Hoi Si Chan (2016), Sehrish GuL, Faiza Irshad \& Khalid Zaman (2011).

ROE $=\beta 0+\beta 1$ SIZE $+\beta 2 N P L+\beta 3$ INF $+\beta 4$ GDP $+\beta 5$ CAPITAL $+\beta 5$ LOAN $+\beta 5$ DEPOSI $+\beta 6 N I M+\beta 7 N I+$ $\beta 8 \mathrm{OI}+\varepsilon$.

Where:

$\beta 0$ : Free coefficient.

$\beta 1, \beta 2, \beta 3, \beta 4, \beta 5, \beta 6, \beta 7, \beta 8$ : unknown parameters.

ع: Error.

Dependent variable: ROE: Return on asset.

Independent variable: SIZE: Firm size.

NPL: Non-performance loan.

INF: Inflation rate.

GDP: Gross domestic product.

CAPITAL: Capital to asset.

LOAN: Total loan to total asset.

NIM: Net interest margin.

OI: Other investment.

NII: Non-interest income.

DEPOSIT: Deposit to asset.

The research sample includes 29 commercial banks' indicators in 5 years from 2013 to 2018 from the business report published every year and the Vietnamese inflation rate from World Bank website. 
Results and Discussion Results: Model 1 result

Table 1: Pearson Correlation 1

\begin{tabular}{|c|c|c|c|c|c|c|c|}
\hline 1 & $\mathrm{ROA}$ & Size & NPL & GDP & \multicolumn{3}{|c|}{ INF capita t Loaratio } \\
\hline \multicolumn{8}{|c|}{ 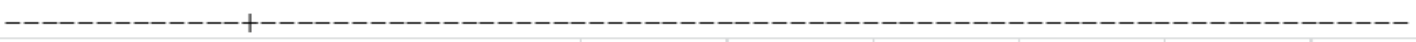 } \\
\hline ROA I & 1.0000 & & & & & & \\
\hline Size | & 0.3130 & 1.0000 & & & & & \\
\hline NPL | & -0.0650 & 0.1638 & 1.0000 & & & & \\
\hline GDP | & 0.0586 & -0.1100 & 0.1701 & 1.0000 & & & \\
\hline INF I & 0.1279 & 0.2122 & -0.1563 & -0.7297 & 1.0000 & & \\
\hline capitalasset | & -0.1233 & -0.7233 & -0.0133 & 0.1913 & -0.3100 & 1.0000 & \\
\hline Loaratio | & -0.0928 & -0.1651 & -0.0778 & 0.1915 & -0.1425 & 0.0657 & 1.0000 \\
\hline Loadeposit o | & -0.0928 & -0.1211 & -0.0428 & 0.1162 & -0.0520 & -0.0572 & 0.6049 \\
\hline Depositratio | & 0.0763 & -0.0349 & -0.0461 & -0.0512 & 0.0724 & 0.1146 & -0.0334 \\
\hline Cashdeposi o | & 0.0083 & 0.0614 & -0.0796 & 0.0256 & -0.0556 & -0.1232 & -0.1285 \\
\hline
\end{tabular}

In this correlation, all of factors have the correlation is in the range from - 0.8 to 0.8 . As result, it does not have multi-regression model in this finding. In addition, the firm size, GDP, inflation rate, deposit ratio and cash to deposit ratio are totally significant positive relation with $R O A$, while non-performance loan, capital to asset ratio and loan to deposit ratio are totally significant negative relation with ROA based on the correlation ratio of this model.

According to result of VIF model, almost factors in financial ratios of banks have the VIF higher than 2, except cash to deposit ratio, deposit ratio and non-performance loan have VIF is lower than 2. However, all of factors in these models have VIF ratio is in the range of 1 to 3 . Therefore, all of factors in regression model are not multi-correlation and it will have higher reliable in regression model.

Table 2: VIF of Model 1

\begin{tabular}{|c|c|c|}
\hline Variable | & VIF & 1/VIF \\
\hline \multicolumn{3}{|c|}{ 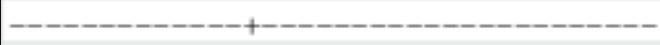 } \\
\hline Loadeposit $0 \quad \mid$ & 2.89 & 0.346003 \\
\hline capitalasset | & 2.37 & 0.421577 \\
\hline INF । & 2.37 & 0.422324 \\
\hline Size 1 & 2.36 & 0.424545 \\
\hline Loaratio | & 2.29 & 0.437331 \\
\hline GDP I & 2.22 & 0.450836 \\
\hline Cashdeposi $\sim 0$ | & 1.92 & 0.521045 \\
\hline Depositratio | & 1.68 & 0.594143 \\
\hline NPL । & 1.13 & 0.881150 \\
\hline \multicolumn{3}{|c|}{ 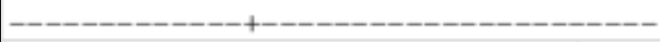 } \\
\hline Mean VIF I & 2.14 & \\
\hline
\end{tabular}

The relation between these factors in financial ratios of banks are constructed in this model. Overall, there are 174 samples that are presented 29 banks in Vietnam from 2013 to 2018 . The R-square is nearly 0.15 and $p$-value is nearly to 0 . As a result, there has at least one factor that can influence on ROA. In 
the case of factors, only firm size, GDP and capital ratios have positively relationship with return on asset or profitability ratio.

To be more detailed, for the size of firms, the coefficient is nearly 0.0073 and $p$-value is nearly to 0 . As a result, it is believed that it has have positively relationship with return on asset or profitability ratio. To be more explained, it is true that when banks can increase the branches in some provinces, the ROA is developed that can increase more income of factories. Therefore, the manager of banks should increase this factor to control the financial process of banks.

In case of GDP, the coefficient is nearly 0.071 and p-value is nearly to 0.002 . As a result, it is believed that it has have positively relationship with return on asset or profitability ratio. To be more explained, it is true that when the government can control the economic in Vietnam or can improve the GDP of economic, the ROA is developed that can increase more income of factories. Therefore, the government should increase this factor to control the financial process of banks.

In case of capital ratio, the coefficient is nearly 0.103 and $p$-value is nearly to 0 . As a result, it is believed that it has have positively relationship with return on asset or profitability ratio. To be more explained, it is true that when banks can increase the capital or equity of firms, the ROA is developed that can increase more income of factories. Therefore, the manager of banks should increase this factor to control the financial process of banks.

Model 2 result Table 13: VIF Model 2

\begin{tabular}{|c|c|c|}
\hline Variable | & VIF & $1 / \mathrm{VIF}$ \\
\hline \multicolumn{3}{|c|}{-------------+----------------------} \\
\hline Size | & 2.81 & 0.356070 \\
\hline capitalasset | & 2.65 & 0.377483 \\
\hline INF | & 2.51 & 0.398373 \\
\hline GDP | & 2.29 & 0.435781 \\
\hline NPL । & 1.34 & 0.744335 \\
\hline OI 1 & 1.33 & 0.751180 \\
\hline NIM | & 1.25 & 0.801805 \\
\hline NII | & 1.24 & 0.807593 \\
\hline Loaratio | & 1.19 & 0.843705 \\
\hline Depositratio | & 1.05 & 0.948431 \\
\hline \multicolumn{3}{|c|}{-------------+----------------------} \\
\hline Mean VIF | & 1.77 & \\
\hline
\end{tabular}

According to result of VIF model, firm size, asset of capital and inflation rate have the VIF higher than 2, other factors in financial performances have vif is lower than 2. However, all of factors in these models have VIF ratio is in the range of 1 to 3 . Therefore, all of factors in regression model are not multi-correlation and it will have higher reliable in regression model.

The relation between these factors in financial ratios of banks are constructed in this model. Overall, there are 174 samples that are presented 29 banks in Vietnam from 2013 to 2018 . The $p$-value is nearly to 0 . As a result, there has at least one factor that can influence on ROE. In the case of factors, firm size, GDP, inflation rate and net interest margin have positively relationship with return on equity or profitability ratio. 
In case of GDP, the coefficient is nearly 0.76 and p-value is nearly to 0 . As a result, it is believed that it has have positively relationship with return on equity or profitability ratio.

In case of net interest margin, the coefficient is nearly 2.46 and p-value is nearly to 0 . As a result, it is believed that it has have positively relationship with return on equity or profitability ratio.

In case of inflation rate, the coefficient is nearly 2.2 and p-value is nearly 0.023 . As a result, it is believed that it has have positively relationship with return on equity or profitability ratio.

Table 14: Fixed Effect Model 2

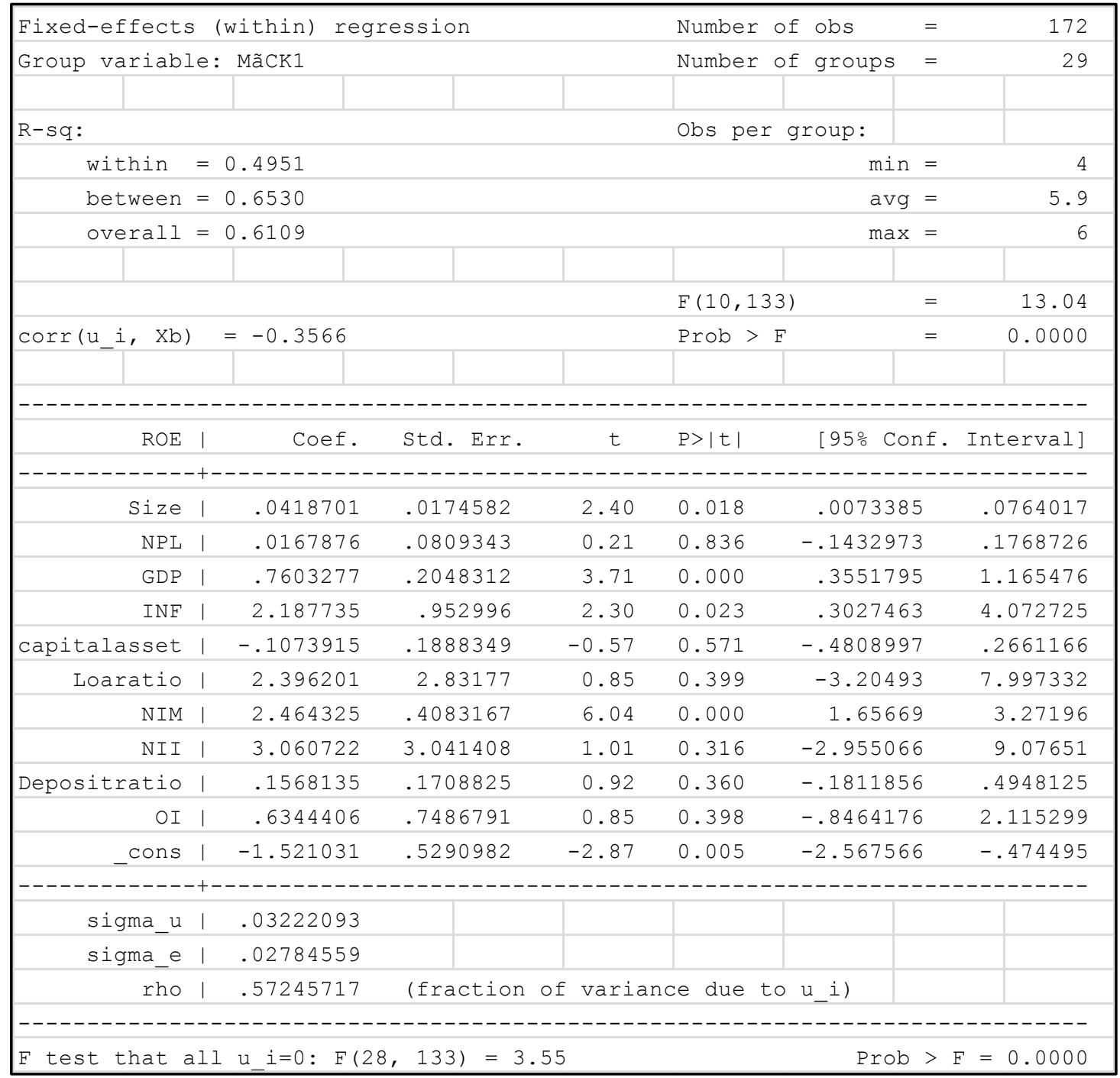

The relation between these factors in financial ratios of banks are constructed in this model. Overall, there are 174 samples that are presented 29 banks in Vietnam from 2013 to 2018 . The $p$-value is nearly to 0 . As a result, there has at least one factor that can influence on ROE. In the case of factors, firm size, GDP, inflation rate and net interest margin have positively relationship with return on equity or profitability ratio.

In case of GDP, the coefficient is nearly 0.76 and p-value is nearly to 0 . As a result, it is believed that it has have positively relationship with return on equity or profitability ratio.

In case of net interest margin, the coefficient is nearly 2.46 and p-value is nearly to 0 . 
In case of inflation rate, the coefficient is nearly 2.2 and p-value is nearly 0.023 . As a result, it is believed that it has have positively relationship with return on equity or profitability ratio.

Discussion: Based on the result of model, almost financial ratios in banking can influence on the financial performance of banks that are the profitability ratio (Return on asset and return on equity). These profitability ratios are important to demonstrate the business process of banks in Vietnam.

For return on asset (ROA), almost factors in external economic that are GDP and inflation rate have positively relationship with return on asset. It is believed that governance has important part to control the ROA of banks. However, the inflation rate is not good for the economic in Vietnam. As a result, the managers should manage this factor suitable to improve the ROA of banks and reduce risk in economic.

In case of some financial performance, some ratios in non-performance loan, loan ratios or income ratios has relationship with return on asset (ROA). As a result, financial performance in banks and equity performances are suitable for banks to conduct the financial strength that are included the profitability (ROA). Therefore, these banks should improve these factors by increasing branches of banks or control the bad debt for these banks to improve the deposit.

\section{Main Text (Review only)}

This section may be divided into subsections or may be combined.

\section{Conclusions}

After analyzing the main determinants of commercial bank's profitability in Vietnam from 2013 to 2018 we can conclude that the empirical findings are relatively consistent with the expected results. Hence, non-performance loan, firm size, inflation rate, gross domestic product, capital to asset, total loan to total asset, loan to deposit ratio, deposit to asset ratio, cash to deposit ratio, deposit to asset ratio have influence on commercial bank profitability, both on ROA and ROE. This validates the objective of Vietnam integrations to enhance competition on markets.

As a policy recommendation for authorities we suggest a better oversight for total loan to total asset and loan to deposit ratio and the encouraging of bank competition. For banks' those in charge of governance we also recommend to monitor the capital to asset ratio, to diversify the sources of revenues and to to optimize costs.

As a future direction of research, we plan to strengthen the analysis by extending the period and by increasing the sample in the groups of banks.

\section{Data Availability (excluding Review articles)}

This section should describe how readers may access the data underlying the findings of the study.

\section{References}

1. Adeusi, S. O., Kolapo, F. T., \& Aluko, A. O. (2014). Determinants of commercial banks' profitability panel evidence from Nigeria.

2. Anbar, A., \& Alper, D. (2011). Bank specific and macroeconomic determinants of commercial bank profitability: Empirical evidence from Turkey. Business and economics research journal, 2(2), 139-152.

3. Athanasoglou, P. P., Asimakopoulos, I. G., \& Georgiou, E. A. (2005). The effect of merger and acquisition announcement on Greek bank stock returns. Economic Bulletin, (24), 27-44. 
4. Athanasoglou, P., Delis, M., \& Staikouras, C. (2006). Determinants of bank profitability in the South Eastern European region.

5. Barnes, M. L., \& Lopez, J. A. (2006). Alternative measures of the Federal Reserve Banks' cost of equity capital. Journal of Banking \& Finance, 30(6), 1687-1711.

6. Bentum, W. (2012). The Determinants of Profitability of the Commercial Banks in Ghana during the Recent Years of Global Financial Crisis. Retrieved July, 15, 2014.

7. Bikker, J. A., \& Hu, H. (2002). Cyclical patterns in profits, provisioning and lending of banks and procyclicality of the new Basel capital requirements. PSL Quarterly Review, 55(221).

8. Bordeleau, É., \& Graham, C. (2010). The impact of liquidity on bank profitability (No. 2010, 38). Bank of Canada working paper.

9. Bourke, P. (1989). Concentration and other determinants of bank profitability in Europe, North America and Australia. Journal of Banking \& Finance, 13(1), 65-79.

10. Brown, C., \& Davis, K. (2009). Capital management in mutual financial institutions. Journal of Banking \& Finance,

11. Dietrich, A., \& Wanzenried, G. (2009, February). What determines the profitability of commercial banks? New evidence from Switzerland. In 12th conference of the Swiss society for financial market researches, Geneva (pp. 2-39).

12. Duca, J. V., \& McLaughlin, M. M. (1990). Developments affecting the profitability of commercial banks. Fed. Res. Bull., 76, 477.

13. Flamini, V., Schumacher, M. L., \& McDonald, M. C. A. (2009). The determinants of commercial bank profitability in Sub-Saharan Africa (No. 9-15). International Monetary Fund.

14. Goddard, J., Molyneux, P., \& Wilson, J. O. (2004). The profitability of European banks: a cross-sectional and dynamic panel analysis. The Manchester School, 72(3), 363-381.

15. Gul, S., Irshad, F., \& Zaman, K. (2011). Factors Affecting Bank Profitability in Pakistan. Romanian Economic Journal, 14(39).

16. Gul, S., Irshad, F., \& Zaman, K. (2011). Factors Affecting Bank Profitability in Pakistan. Romanian Economic Journal, 14(39).

17. Hu, J. L., Su, Y. Y., \& Chen, C. P. (2008). Efficiency of nationwide banks in China. Journal of American Academy of Business, 13(2), 84-90.

18. Lai, M. M., Melvin, L., Balachandher, K. G., Nor, F. M., \& Guru, K. (2002). An Examination of the Random Walk Model and Technical Trading Rules in the Malaysian Stock Market. Quarterly Journal of Business \& Economics, 41.

19. Miller, S. M., \& Noulas, A. G. (1997). Portfolio mix and large-bank profitability in the USA. Applied Economics, 29(4), 505-512.

20. Molyneux, P., \& Thornton, J. (1992). Determinants of European bank profitability: A note. Journal of banking \& Finance, 16(6), 1173-1178. 
21. Naceur, S. B., \& Goaied, M. (2001). The determinants of the Tunisian deposit banks' performance. Applied Financial Economics, 11(3), 317-319.

22. Nathan, A., \& Neave, E. H. (1992). Operating efficiency of Canadian banks. Journal of Financial Services Research, 6(3), 265-276. 64

23. Onuonga, S. M. (2014). The Analysis of Profitability of Kenyas Top Six Commercial Banks: Internal Factor Analysis. American International Journal of Social Science, 3(5), 94-103.

24. Pasiouras, F., \& Kosmidou, K. (2007). Factors influencing the profitability of domestic and foreign commercial banks in the European Union. Research in International Business and Finance, 21(2), 222-237.

25. Perry, P. (1992). Do banks gain or lose from inflation? Journal of Retail Banking, 14(2), 25-31.

26. San, O. T., \& Heng, T. B. (2013). Factors affecting the profitability of Malaysian commercial banks. African Journal of Business Management, 7(8), 649-660.

27. Sufian, F. (2011). Profitability of the Korean banking sector: Panel evidence on bank-specific and macroeconomic determinants. Journal of economics and management, 7(1), 43-72.

28. Sufian, F., \& Chong, R. R. (2008). Determinants of bank profitability in a developing economy: empirical evidence from the Philippines. Asian Academy of Management Journal of Accounting \& Finance, 4(2).

29. Syafri, M. (2012, September). Factors affecting bank profitability in Indonesia. In The 2012 International Conference on Business and Management (Vol. 237, No. 9, pp. 7-8).

30. Trujillo-Ponce, A. (2013). What determines the profitability of banks? Evidence from Spain. Accounting \& Finance, 53(2), 561-586.

31. Vong, P. I., \& Chan, H. S. (2009). Determinants of bank profitability in Macao. Macau Monetary Research Bulletin, 12(6), 93-113.

32. Vong, P. I., \& Chan, H. S. (2009). Determinants of bank profitability in Macao. Macau Monetary Research Bulletin, 12(6), 93-113.

33. Wagner, W. (2007). The liquidity of bank assets and banking stability. Journal of Banking \& Finance, 31(1), 121-139.

34. Website Source: https://data.worldbank.org/ 